\title{
Pengaruh Model Pembelajaran Auditory Intellectualy Repitition (Air) Berbantuan Alat Peraga Terhadap Pemahaman Konsep Matematis Siswa PadaMateri Limas Kelas VIII
}

\author{
Christi Jayanti D.A.P ${ }^{1}$, Rosmaiyadi $^{2}$, Mariyam $^{3}$. \\ Pendidikan Matematika, STKIP Singkawang, Singkawang, Indonesia
} Cristijayanti782@gmail.com ${ }^{1}$,Rosmaiyadialong@gmail.com ${ }^{2}$,Mariyam.180488@gmail.com ${ }^{3}$

\author{
Keywords : \\ Auditory Intellectualy \\ Repetition (AIR); pemahaman \\ konsep matematis; Alat peraga; \\ Limas
}

\begin{abstract}
Penelitian ini bertujuan: (1) Untuk mengetahui perbedaan kemampuan pemahaman konsep matematis siswapada pembelajaran modelAudiotory Intellectualy Repetition berbantuan alat peraga dengan siswa yang mendapat model pembelajaran konvensional; (2) Untuk mengetahuibesar pengaruh model pembelajaranAudiotory Intellectualy Repetition berbantuan alat peraga terhadap kemampuan pemahaman konsep matematis siswa pada materi limas; (3)Untuk mengidentifikasi keterlaksanaan pembelajaran siswa dengan model pembelajaranAudiotory Intellectualy Repetition berbantuan alat peraga pada materi limas; (4) Untuk mengidentifikasi motivasi siswa dengan model pembelajaranAudiotory Intellectualy Repetition berbantuan alat peraga pada materi limas.Jenis penelitian ini adalah Quasi Eksperimentdengan bentuk Posttest-Only Control Design. Instrumen yang digunakan adalah tes kemampuan pemahaman konsepmatematis siswa,lembar pengamatan keterlaksanaan model pembelajaran dan lembar angket motivasi siswa.Hasilpenelitian: (1) Terdapat perbedaankemampuan pemahaman konsep matematis siswa dengan modelAudiotory Intellectualy Repetition berbantuan alat peraga dengan siswa yang mendapat pembelajaran konvensional; (2) model pembelajaranAudiotory Intellectualy Repetition berbantuan alat peraga memiliki pengaruh yang besar terhadap kemampuan pemahaman konsep matematis siswa pada materi limas; (3) keterlaksanaan model pembelajaran Auditory Intellectualy Repetitionberbantuan alat peraga pada materi limas dapat tercapai dengan baik; (4) motivasi belajar siswa tergolong tinggi ketika diterapkan model pembelajaran Auditory Intellectualy Repetition berbantuan alat peraga pada materi limas.
\end{abstract}

\section{INTRODUCTION}

Pendidikan merupakan suatu proses perubahan tingkah laku dan kemampuan seseorang menuju ke arah yang lebih baik berupa kemajuan dan peningkatan. Ghufron (2017) mengungkapkan bahwa pendidikan adalah upaya sadar yang dilakukan untuk meningkatkan kemampuan individu agar dapat menentukan kehidupan secara mandiri. Pendidikan mempunyai peranan yang sangat penting bagi 
kehidupan manusia. Sehingga dengan adanya pendidikan seorang individu dapat menentukan kehidupan yang lebih baik dan tidak bergantung kepada orang lain. Tujuan pendidikan pada umumnya adalah menyiapkan individu yang dapat membentuk manusia berwawasan luas dan berpikir kreatif serta mandiri sehingga mampu memecahkan permasalahan-permasalahan yang dihadapi serta dapat memberikan solusi untuk sebuah permasalahan yang diberikan terutama pada permasalahn matematika.

Matematika merupakan salah satu komponen dari serangkaian mata pelajaran yang mempunyai peranan penting dalam pendidikan (Sundayana, 2014: 2). Selain itu, matematika merupakan ilmu yang terstruktur dan saling berkaitan antara satu topik dengan topik lainnya (Romli, 2016). Sebagai ilmu yang saling berkaitan, siswa harus memiliki kemampuan dalam menghubungkan antara topik di dalam matematika. Kemampuan untuk menghubungkan kemampuan tersebut, terdapat lima kemampuan yang harus dimiliki siswa dalam belajar matematika yangb telah ditetapkan oleh The National Council of Teachers of Mathematics (dalam Musriliani dkk, 2015) salah satunya yaitu kemampuan koneksi.

Sesuai dengan yang dikemukakan NCTM (2000) mengenai perlunya mengembangkan pemahaman dan penggunaan keterkaitan (koneksi) matematika dalam ide atau pemikiran matematika peserta didik. NCTM menyatakan bahwa program pembelajaran disekolah mulai dari taman kanak-kanak sampai dengan kelas XII seharusnya memungkinkan peserta didik untuk mengenali dan menggunakan koneksi antar ide-ide atau gagasan dalam matematika, memahami bagaimana keterkaitan atau koneksi ide-ide dalam matematika dan menyusunnya untuk menghasilkan suatu hubungan yang koheren, serta mengenali dan menawarkan matematika dalam konteks-konteks permasalahan diluar matematika.

Kemampuan koneksi merupakan salah satu kemampuan berpikir tingkat tinggi yang sangat penting dan harus dikembangkan karena dalam pembelajaran matematika setiap konsep berkaitan satu sama lainnya. Standar kemampuan koneksi dalam pembelajrana matematika yaitu mengenal dan menggunakan hubungan diantara ide-ide matematis, memahami bagaimana ide matematika saling berhubungan dan membangun ide satu sama lain untuk menghasilkan keseluruhan yang saling terkait, mengenal dan menerapkan ilmu matematika diluar konteks matematika (Musriliani, 2015:2). Melalui aturan matematika dengan bidang studi lain, pada aspek ini siswa mampu mengaitkan konsep matematika ke ilmu lain untuk memecahkan suatu masalah, mencari dan memahami antara konsep atau aturan matematika dengan aplikasi pada kehidupan nyata, pada aspek ini siswa mampu memecahkan masalah yang berkaitan dengan kehidupan sehari-hari dengan menggunakan konsep matematika. Dapat disimpulkan kemampuan koneksi matematis siswa adalah kemampuan siswa dalam menghubungkan antar konsep matematika itu sendiri maupun dengan ilmu selain matematika atau dalam kehidupan sehari-hari.

Bruner menyatakan bahwa anak perlu menyadari bagaimana hubungan antar konsep, karena antara sebuah bahasan dengan bahasan matematika lainnya saling berkaitan (Lestari 2014: 37). Selanjutnya Yuniawati $(2011 ; 106)$ menyatakan kemampuan koneksi matematik sangat penting untuk dimiliki siswa agar siswa mampu membuat suatu hubungan yang bermakna antar konsep matematika atau antara konsep dengan bidang lain ataupun dengan kehidupan atau lingkungan sekitar siswa. Selain itu, jika kemampuan koneksi telah dimiliki oleh siswa maka akan mempermudah siswa untuk memahami suatu konsep. Apabila siswa dapat menghubungkan konsep-konsep matematika, maka pemahaman mereka akan lebih mendalam dan lebih bertahan lama, namun jika siswa masih sulit menghubungkan materi yang mereka pelajari dengan prasyarat yang sudah mereka kuasai, maka konsep-konsep yang telah dipelajari tidak bertahan lama dalam ingatan siswa. Berdasarkan uraian tersebut peneliti berpendapat bahwa kemampuan koneksi matematis sangat penting dimiliki oleh setiap siswa, karena ilmu matematika merupakan satu kesatuan dan tidak saling terpisahkan dalam berbagai topik.

Namun kenyataannya dalam pembelajaran kemampuan koneksi siswa masih rendah hal ini diketahui dari hasil penelitian Sugiman (2008:10) yang mengungkapkan bahwa "rata-rata persentase penguasaan untuk setiap aspek koneksi adalah koneksi inter topik matematika 63\%, antar topik 
matematika $41 \%$, matematika dengan pelajaran lain 56\%, dan matematika dengan kehidupan 55\%". Kemudian didukung oleh penelitian Warih, dkk (2016) menunjukan bahwa siswa melakukan kesalahan pada indikator menggunakan hubungan diantara ide-ide matematis dan siswa belum dapat menghubungkan satu konsep dengan konsep lain yang sudah dipelajari untuk menyelesaikan soal koneksi matematis, siswa tidak mengenali ide-ide matematis, dan siswa tidak dapat menggunakan ideide matematis. Berdasarkan hasil penelitian tersebut dapat diketahui bahwa kemampuan koneksi matematika masih rendah, khususnya dalam menyelesaikan soal matematika. Dalam menyelesaikan soal matematika, siswa hanya mempelajari apa yang diajarkan oleh guru tanpa mencari tahu dari sumber lain.

Hal ini juga didukung dari hasil prariset yang dilakukan peneliti pada hari Senin 13 Agustus 2018 di Mts Alfatah Singkawang dengan memberi satu soal yang mengandung salah satu indikator koneksi yaitu mengenali dan memanfaatkan hubungan-hubungan antar gagasan matematika kepada 30 orang siswa kelas VIII. Hasilnya menunjukan bahwa rata-rata kemampuan koneksi siswa tergolong masih rendah.

Dari hasil prariset diketahui $60 \%$ dari 30 orang siswa mengalami kesulitan dalam memahami soal. Pada soal yang diujikan siswa diminta untuk mencari keliling bangun persegi panjang yang diketahui luasnya yaitu $280 \mathrm{~cm}$ dan lebarnya adalah $14 \mathrm{~cm}$. Berdasarkan salah satu hasil pekerjaan siswa pada Gambar 1, siswa tidak dapat mencari keliling bangun persegi panjang dengan mengaitkan luas persegi panjang yang diketahui. Siswa melakukan kesalahan dalam menyelesaikan soal dengan langsung ke rumus keliling persegi. Cara yang dilakukan siswa tersebut tidak tepat untuk menyelesaikan soal yang diujikan. Pada Gambar 1 menunjukan bahwa kemampuan koneksi antar konsep matematika siswa masih rendah. Rendahnya kemampuan koneksi matematis siswa diduga karena pembelajaran masih didominasi oleh guru, sehingga peserta didik kurang terlibat secara aktif dalam pembelajaran. Salah satu penyebab timbulnya masalah tersebut adalah karena pembelajaran matematika hanya berfokus pada guru sehingga peserta didik tidak memiliki peranan dalam mengoneksikan permasalahan yang diberikan. Karena kurangnya peranan siswa dalam mengkoneksikan permasalahan menyebabkan siswa kesulitan dalam menyelesaikan soal kemampuan koneksi matematis siswa dan banyak siswa yang tidak tuntas dalam mengerjakan soal kemampuan koneksi matematis. Kurangnya kemampuan siswa dalam mengkoneksikan permasalahan tersebut juga didominasi oleh guru yang kurang dalam memberikan latihan-latihan soal koneksi, bahkan ada juga guru yang tidak memberikan latihan-latihan soal koneksi. terbukti dari hasil prariset, banyak siswa yang tidak tuntas dalam menyelesaikan soal yang mengandung salah satu indikator kemampuan koneksi.

Banyak faktor yang menyebabkan siswa melakukan kesalahan dalam menyelesaikan soal matematika. Menurut Amir (2015:8) faktor-faktor penyebab kesalahan yang dilakukan siswa dalam menyelesaikan soal matematika dapat dipandang sebagai faktor kesulitan yang dialami siswa. Hal ini disebabkan siswa mengalami kesulitan dalam menyelesaikan soal dimungkinkan akan melakukan kesalahan menjawab sebaliknya siswa yang melakukan kesalahan menjawab dimungkinkan sebelumnya mengalami kesulitan. Salah satu faktor internal yang perlu diperhatikan saat siswa melakukan kesalahan adalah dengan cara gaya kognitif. Kognitif erat kaitannya dengan kemampuan seseorang untuk memproses informasi sebagai respon dari rangsangan yang berasal dari lingkungan. Karena kognitif merupakan bagian dari karakteristik siswa. Kognitif adalah kebiasaan seseorang dalam pengolahan informasi yang digunakan dalam proses belajar yaitu mengamati, berpikir, menyelesaikan masalah dan mengingat.

Dalam pembelajaran matematika, diperlukan beberapa keterampilan agar siswa dapat memahami materi, lancar menggunakan dan melakukan prosedur sehingga mampu menyelesaikan masalah dengan tepat dan benar. Keterampilan yang dimaksud adalah kemampuan melakukan proses dalam memahami isi dari materi matematika untuk mengahasilkan keahlian dalam matematika (Mariyam, Nindy Citroresmi P, Rika Wahyuni 2018: 66). Materi yang dipilih dalam penelitian adalah materi geometri, materi geometri merupakan salah satu materi yang ada di kelas VIII. Pertimbangan peneliti 
mengambil materi geometri karena materi geometri sangat mendukung kemampuan koneksi matematis siswa dan berdasarkan hasil wawancara dengan guru matematika di Mts Alfatah Singkawang diketahui rata-rata nilai ulangan harian siswa pada materi geometri sangat rendah, banyak siswa yang tidak tuntas dan harus melakukan perbaikan. Salah satu submateri pada materi geometri yang memerlukan kamampuan koneksi adalah submateri kubus dan balok.

Pembelajaran matematika disekolah hanya mengejar nilai saja tanpa memperhatikan mutu dan aspek matematika yang saling berhubungan akibatnya proses berpikir peserta didik menjadi terhambat sehingga peserta didik mengalami kesulitan dalam menyelesaikan masalah apalagi dalam mengkoneksikan antar permasalahan. Dalam pelaksanaan matematika didalam kelas umumnya hanya terfokus kepada ketercapaian target materi menurut buku ajar ataupun kurikulum, bukan pada materi yang siswa pelajari, hal ini menyebabkan siswa hanya mengahafal konsep dan tidak memahami maksud dari isinya (Nindy Citroresmi P., Nurhayati 2017: 13). Menurut Mulyana (2003) pengajaran geometri yang baik harus sesuai dengan kemampuan anak. Kemampuan anak dapat dilihat dari proses berpikir dan penerapan keterampilan dalam pemecahan masalah geometri. Penerapan teori Van Hiele diyakini dapat mengatasi kesulitan siswa dalam pemecahan masalah dalam geometri. Hal ini disebabkan karena teori Van Hiele menjelaskan perkembangan berpikir siswa dalam belajar geometri. Dengan demikian anak dapat memperkaya pengalaman dan cara berpikirnya, selain itu sebagai persiapan untuk meningkatkan tahap berpikirnya ke tahap yang lebih dari tahap sebelumnya.

Berdasarkan teori van Hiele (1954) siswa akan melalui lima tingkat (level) berpikir dalam memahami geometri, yaitu: tingkat 0 (visualisasi), tingkat 1 (analisis), tingkat 2 (deduksi informal), tingkat 3 (deduksi), dan tingkat 4 (rigor). Dalam setiap tingkat berpikir Van Hiele juga dibutuhkan keterampilan-keterampilan dasar dalam memecahkan masalah geometri yang berbeda-beda. Misalnya, untuk tingkat 0 (visualisasi) dan tingkat 1 (analisis) dilihat dari keterampilan verbal (verbal skill) mempunyai karakteristik yang berbeda, yaitu: untuk tingkat 0 (visualisasi) siswa hanya mampu mengelompokkan gambar segiempat dan memberikan nama jenis segiempat tersebut, sedangkan untuk tingkat 1 (analisis) siswa sudah dapat secara akurat menjelaskan sifat berbagai gambar segiempat.

Berdasarkan permasalahan yang telah dibahas sebelumnya maka penulis tertarik untuk melakukan penelitian dengan judul "Analisis Kemampuan Koneksi Matematis Siswa Dalam Memecahkan Masalah Geometri Berdasarkan Tingkat Berpikir Van Hiele di kelas VIII MTS Alfatah Singkawang"

\section{METHOD}

Penelitian ini adalah jenis penelitian kuantitatif dengan metode eksperimen, penelitian ini menggunakan Quasi Eksperimen dengan bentuk Posttest-Only Control Design.menggunakan tes akhir atau post-test untuk melihat perbedaan kelas yang diberikan perlakuan dengan kelas kontrol. Secara bagan, rancangan itu dapat dilukiskan seperti pada Tabel 1 sebagai berikut:

Tabel 1. Rancangan

\begin{tabular}{llll} 
Eksperimen & $\mathbf{X}$ & $\longrightarrow$ & $\boldsymbol{O}_{1}$ \\
\hline Kontrol & $\mathbf{C}$ & $\longrightarrow$ & $\boldsymbol{O}_{2}$ \\
\hline & & \\
\hline
\end{tabular}

Keterangan:

$\mathrm{X}=$ Model pembelajaran AIR 
$\mathrm{C}=$ Model pembelajaran langsung

$\mathrm{O}_{1}=$ Post-test yang diberikan model pembelajaran AIR

$\mathrm{O}_{2}=$ Post test yang diberikan model pembelajaran langsung

Populasi dalam penelitian ini adalahadalah seluruh siswa kelas VIII SMP Torsina Singkawang yang terdiri dari 2 kelas yaitu kelas VIIIA, VIIIB. Sedangkan sampel dalam penelitian ini sama dengan populasi, yaitu kelas VIII SMP Torsina yang terdiri dari kelas VIII A dan VIII B. Dalam penelitian ini sampel yang akan menjadi kelas eksperimen adalah kelas VIIIB yang memiliki hasil belajar lebih rendah dari kelas VIIIA,sampel yang digunakan adalah teknik Sampling Jenuh.Teknik pengumpulan data dalam penelitian ini adalah tes kemampuan pemahaman konsep matimatis, lembar pengamatan keterlaksanaan, angket motivasi belajar. Instrumen pengumpulan data dalam penelitian ini yaitu:a)soal-soal uraian yang diberikan dalam bentuk posttest yang merupakan tes kemampuan pemahaman konsep diukur sesuai dengan pedoman penskoran kemampuan pemahaman konsepmetematis siswa b) lembar keterlaksanaan pembelajaran yang dihitung persentase rata-rata keseluruhan dengan rumus skor keseluruhanyaitu dengan menghitungpersentase pada tahapan kegiatan pembelajaran dari masing-masing pengamat; c) angket motivasi belajar siswa, angket ini digunakan untuk mengukur tingkat motivasi belajar siswa menggunakan model pembelajaran Audiotory Intellectualy Repetition.

Data yang akan dianalisis dalam penelitian ini diperoleh dari tes kemampuan pemahaman konsep matematis, tes dilakukan setelah dilaksanakan model pembelajaran Audiotory Intellectualy Repetitionpada kelas eksperimen dan kelaas kontrol, dengan pemberian soal(posttest). Dari skor postest yang telah diperoleh dihitung rata-rata hasil postestlalu dilihat perbedaan kemampuan pemahaman konsep siswa diggunakan rumus (varians gabungan) kemampuan pemahaman konsep matematis dari hasil tersebut.

Selain data tes perbedaan kemempuan pemahaman konsep matematis siswa pada kelas eksperimen dan kontrol, dilakukan juga penghitungan untuk mengetahui besarnya pengaruh model AIR berbantuan alat peraga, kemudian data hasil lembar keterlaksanaan pembelajaran dan data motivasi siswa juga dianalisis. Data besarnya pengaruh model pemebelajaran AIR menggunakan rumus effect Size.Data keterlaksanaan pembelajaran dianalisis dengan menghitung presentase keterlaksanaan keseluruhan dari hasil kedua pengamat. Data motivasi siswa dianalisis dengan menghitung skor motivasi belajar siswa secara individu dilanjutkan dengan menghitung rata-rata keseluruhan hasil angket motivasi.

\section{RESULTS AND DISCUSSIONS}

Berdasarkan penelitian yang telah dilakukan, hasil penelitian ini meliputi: (1) perbedaan kemampuan pemahaman konsep matematis siswa dengan model AIR berbantuan alat peraga dengan siswa yang menggunakan pembelajaran konvensional, (2) melihat besarnya pengaruh model pembelajaran AIR berbantuan alat peraga terhadap kemampuan pemahaman konsep matematis siswa, (3) keterlaksanaan pembelajaran menggunakan model AIR berbantuan alat peraga, (4) motivasi belajar siswa.

\section{Kemampuan Pemahaman Konsep Matematis Siswa}

Hasil posttest kelas eksperimen dan kelas kontrol. Berdasarkan hasil skor tertingi, skor terendah,ratarata, Standar Deviasi yang telah dilakukan maka diperoleh hasil yang dapat dilihat pada tabel 2 berikut. 
Tabel 2. Rekapitulasi Hasil Posttes Kemampuan Pemahaman Konsep Matematis Siswa Kelas Eksperimen dan Kelas Kontrol

\begin{tabular}{lll}
\hline Statistika & Eksperimen & Kontrol \\
\hline Skor Tertinggi & 87,5 & 81,25 \\
Skor Terendah & 68,75 & 50 \\
Rata-rata & 81,25 & 70,1 \\
Standar Deviasi & 12,64 & 11,35 \\
\hline Jumlah Siswa & $\mathbf{2 3}$ & $\mathbf{2 3}$ \\
\hline
\end{tabular}

Dari tabel 2 di atas dapat dilihat bahwa skor tertinggi, skor terendah, rata-rata dan standar deviasi pada kelas eksperimen lebih tinggi dibandingkan pada kelas kontrol, dengan jumlah siswa pada kelas eksperimen sama dengan jumlah siswa pada kelas kontrol yaitu 23 orang, jadi dapat dilihat bahwa terdapat perbedaan kemampuan pemahaman konsep matematis siswa pada kelas eksperimen dan kelas kontrol ketika diberikan soal yang mengandung empat indikator pemahaman konsep matematis siswa.

Berdasarkan perhitungan diperoleh nilai untuk setiap indikator kemampuan pemahaman konsep matematis siswa di kelas eksperimen dan kelas kontrol akan disajikan pada Tabel 3 sebagai berikut:

Tabel 3. Rekapitulasi Hasil Kemampuan Pemahaman Kosep Matematis Siswa Untuk Setiap Indikator

\begin{tabular}{|c|c|c|c|c|c|c|}
\hline \multirow[t]{2}{*}{$\begin{array}{l}\text { Indikator kemampuan } \\
\text { pemahaman konsep }\end{array}$} & \multicolumn{2}{|c|}{$\begin{array}{l}\text { Kelas } \\
\text { Eksperimen }\end{array}$} & \multirow[t]{2}{*}{ Persentasi } & \multicolumn{2}{|c|}{ Kelas Kontrol } & \multirow[t]{2}{*}{ Persentas } \\
\hline & $\begin{array}{l}\text { Jumlah } \\
\text { Skor }\end{array}$ & $\begin{array}{l}\text { Rata- } \\
\text { rata }\end{array}$ & & $\begin{array}{l}\text { Jumlah } \\
\text { Skor }\end{array}$ & $\begin{array}{l}\text { Rata- } \\
\text { rata }\end{array}$ & \\
\hline $\begin{array}{l}\text { Menyatakan ulang sebuah } \\
\text { konsep }\end{array}$ & 73 & 3,1 & $77,5 \%$ & 62 & 2,9 & $72,5 \%$ \\
\hline $\begin{array}{l}\text { Mengkasifiksikan konsep } \\
\text { berdasarkan kriterianya }\end{array}$ & 79 & 3,4 & $85 \%$ & 70 & 3 & $75 \%$ \\
\hline $\begin{array}{l}\text { Memberikan contoh dan } \\
\text { non-contoh }\end{array}$ & 77 & 3,3 & $82,5 \%$ & 70 & 3 & $75 \%$ \\
\hline $\begin{array}{l}\text { Alogaritma dalam } \\
\text { pemecahan masalah }\end{array}$ & 72 & 3,2 & $80 \%$ & 61 & 2,6 & $65 \%$ \\
\hline Jumlah & 301 & 13 & $81,25 \%$ & 263 & 11,5 & $71,87 \%$ \\
\hline
\end{tabular}

Berdasarkan Tabel 3 dapat diketahui bahwa dari setiap indikator kemampuan pemahaman konsep matematis siswa pada kelas eksperimen lebih tinggi dibandingkan kelas kontrol. Peningkatan pada indikator kemampuan pemahaman konsep matematis siswa dapat diperjelas dengan gambar 1 berikut:

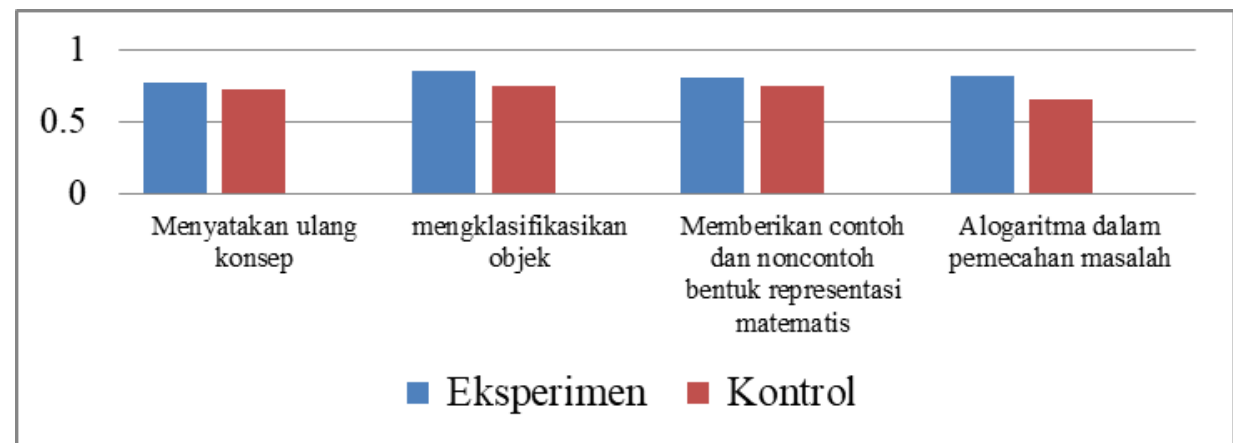

Gambar 1. Diagram Batang Indikator Kemampuan Pemahaman Konsep Kelas Eksperimen dan Kelas Kontrol 
Dari Gambar 1 dapat diketahui bahwa pada kelas eksperimen meningkat lebih tinggi dari pada kelas kontrol dari setiap indikator. Secara deskriftif kemampuan pemahaman konsep matematis siswa pada kelas eksperimen berbeda dengan kelas kontrol, namun secara inferensial nilai tersebut belum tentu memiliki perbedaan yang singnifikan. Oleh karena itu harus dilakukan uji perbedaan rata-rata posttest kelas eksperimen dan kelas kontrol.

Selanjutnya dilakukan uji perbedaan rata-rata posttest kelas eksperimen dan kelas kontrol, namun sebelumnya rata-rata skor posttest kelas eksperimen dan kelas kontrol dilakukan uji normalitas data. Adapun uji normalitas data dengan menggunakan uji statistik chi kuadrat. Berdasarkan perhitungan uji normalitas dapat dilihat rekapitulasi hasil uji normalitas data posttest untuk kelas eksperimen dan kelas kontrol dapat dilihat pada tabel 4 berikut.

Tabel 4. Rekapitulasi Hasil Perhitungan Uji Normalitas

\begin{tabular}{llllll}
\hline Kelompok & $\mathbf{N}$ & $\begin{array}{l}\text { Taraf } \\
\text { Signifikan }\end{array}$ & $\chi^{2}$ hitumg & $\chi^{2}$ tabel & kesimpulan \\
\hline Eksperimen & 23 & $5 \%$ & 520,38 & 5,99 & $\begin{array}{l}\text { Tidak berdistribusi } \\
\text { normal }\end{array}$ \\
Kontrol & 23 & $5 \%$ & 14,46 & 5,99 & $\begin{array}{l}\text { Tidak berdistribusi } \\
\text { normal }\end{array}$ \\
\hline
\end{tabular}

Pada table 4 di atas, terlihat bahwa hasil perhitungan uji normalitas pada kelas eksperimen diperoleh harga $x_{\text {hitung }}^{2}=520,38$ sedangkan dari tabel kritis uji chi-kuadrat diperoleh $x_{\text {tabel }}^{2}$ untuk jumlah sampel sebanyak 23 dan banyak kelas 5 pada taraf singnifikan $\alpha=5 \%$ adalah 5,99, dari hasil tersebut diketahui bahwa nilai $x_{\text {hitung }}^{2}$ lebih besar dari $x_{\text {tabel }}^{2}(520,38 \geq 5,99)$, maka Ho ditolak dan Ha diterima, artinya data yang terdapat pada kelas eksperimen dari populasi tidak berdistribusi normal. Sedangkan pada hasil perhitungan uji normalitas pada kelas kontrol diperoleh harga $x_{\text {hitung }}^{2}=14,46$ sedangkan dari tabel kritis uji chi-kuadrat diperoleh $x_{\text {tabel }}^{2}$ untuk jumlah sampel sebanyak 23 dan banyak kelas 5 pada taraf singnifikan $\alpha=5 \%$ adalah 5,99 dari hasil tersebut diketahui bahwa $x_{\text {hitung }}^{2}$ lebih dari $x_{\text {tabel }}^{2}(14,46 \geq 5,99)$, maka Ho ditolak dan Ha diterima, artinya data yang terdapat pada kelas kontrol dari populasi tidak berdistribusi normal. Jadi dapat disimpulkan bahwa kelas eksperimen dan kelas kontrol tidak berdistribusi normal. Berdasarkan kesimpulan tersebut, maka pada kelas eksperimen dan kelas kontrol tidak dilakukan uji homogenitas. Untuk melihat perbedaan kemampuan pemahaman konsep matematis siswa dengan menggunakan model AIR berbantuan alat peraga dengan model pembelajaran langsung digunakan Uji Mann Whitney $U$.

Adapun hail perhitungan Uji Mann Whitney $U$ dapat dilihat pada tabel 5 di bawah ini.

Tabel 5. Rekapitulasi Hasil Uji Mann Whitney $U$

\begin{tabular}{lllllll}
\hline Kelompok & $\begin{array}{l}\text { Jumlah } \\
\text { Rank }\end{array}$ & $\begin{array}{l}\text { Nilai } \\
\boldsymbol{U}_{\mathbf{1}}\end{array}$ & ${\text { Nilai } \boldsymbol{U}_{\mathbf{2}}}$ & $\mathbf{Z}$ hitung & $\mathbf{Z}$ tabel & kesimpulan \\
\hline $\begin{array}{l}\text { Ekperimen } \\
\text { Kontrol }\end{array}$ & 705 & 100 & 439 & 1,17 & 0,3790 & $\begin{array}{l}\text { Terdapat } \\
\text { perbedaan }\end{array}$ \\
\hline
\end{tabular}

Berdasarkan tabel 5 diatas, maka dapat dilihat hasil Uji Mann Whitney $U$ dengan jumlah rank pada kelompok eksperimen adalah 705, dan kelompok pada kelas kontrol adalah 366, diperoleh $U_{1}=100$ dan $U_{2}=439$, karena sampel kelompok eksperimen dan kelompok kontrol lebih dari 20 orang maka dilakukan uji Z. maka diperoleh uji $Z_{\text {hitung }}=0,03$ dan $Z_{\text {tabel }}=0,012$. Karena 
$=P R$ Journal of Educational Review and Research

Vol. 1 No. 2, December 2018: 100 - 110

e-ISSN: 2597-9760, p-ISSN: 2597-9752

$Z_{\text {hitung }}>Z_{\text {tabel }}(1,17>0,3790)$, maka Ho ditolak Ha diterima, Artinya terdapat perbedaan

kemampuan pemahaman konsep matematis siswa pada materi limas antara siswa yang mendapatkan pembelajaran dengan model pembelajaran Audiotory Intellectualy Repetition (AIR) berbantuan alat peraga dengan siswa yang mendapat pembelajaran konvensional.

Terdapat perbedaan model pembelajaran AIR berbantuan atal peraga dengan model pembelajaran konvensional, karena pada tahap model pembelajaran AIR dapat membuat siswa mengenali pengetahuannya dengan lebih aktif dan memahami sebuah konsep dari suatu materi, dimana siswa secara aktif membangun sendiri pengetahuannya secara pribadi maupun kelompok, dengan cara mengintegrasikan ketiga aspek, yang terdiri dari Auditory (pendengaran dan keberanian berbicara) aspek ini terdapat pada tahapan ke-tiga yaitu setiap kelompok berdiskusi tentang materi yang pelajari dan menuliskan hasil diskusinya serta selanjutnya untuk dipersentasikan didepan kelas Intellectually (berpikir) aspek ini terdapat pada tahap ke-lima dimana masing-masing kelompok memikirkan cara menerapkan hasil diskusi serta dapat meningkatkan kemampuannya untuk menyelesaikan masalah dari guru dan Repetition (pengulangan) aspek ini terdapat pada tahap ke-enam dimana setelah selesai berdiskusi, siswa mendapat pengulangan materi dengan cara mendapatkan tugas atau kuis setiap individu, sehingga dapat meningkatkan penguasaan dan pengetahuan kontekstual siswa, hal ini membuat siswa untuk lebih mudah memahami sebuah konsep yang diberikan. Salah satu kelebihan model AIR menurut Shoimin (2014:13) adalah siswa memiliki kesempatan lebih banyak dalam memanfaatkan pengetahuan dan keteramampilan secara komprehensif. Model AIR dapat meningkatkan pengetahuan siswa dalam memecahkan masalah yang ada dan mempermudah siswa untuk dapat memahami konsep. Setelah diketahui terdapat perbedaan selanjutnya untuk mengetahui besarnya pengaruh model AIR berbantuan alat peraga akan dihitung mengunkan rumus effect size.

\section{Pengaruh Model Pembelajaran Audiotory Intellectualy Repetition (AIR).}

Besarnya pengaruh model pembelajaran Audiotory Intellectualy Repetition (AIR) berbantuan alat peraga maka dapat dihitung dengan mengunakan rumus effect size. Adapun rekapitulasi hasil perhitungan effect size dapat dilihat pada tabel 6 berikut.

Tabel 6. Rekapitulasi Hasil Perhitungan Effect Size.

\begin{tabular}{lllll}
\hline Kelas & Nilai Rata-rata & Standar Deviasi & Es & keterangan \\
\hline Eksperimen & 81,25 & 12,64 & 0,92 & Tinggi \\
Kontrol & 70,1 & 11,36 & & \\
\hline
\end{tabular}

Dari tabel 6 dapat dilihat bahwa hasil perhitungan effect size $=0,9$ dengan kriteria tinggi dan 0,9 berada pada $\Delta>0,80$. hal ini berarti model pembelajaran Audiotory Intellectualy Repetition (AIR) berbantuan alat peraga memberikan pengaruh yang tinggi terhadap kemampuan pemahaman konsep matematis siswa. AIR ini memberikan pengaruh yang besar terhadap kemampuan pemahaman konsep matematis siswa hal ini dapat dilihat dari kelebihan model AIR itu sendiri. Salah satu kelebihan model pembelajaran AIR menurut Aris (2014: 30) adalah siswa dengan kemampuan rendah dapat merespon permasalahan dengan cara mereka sendiri, ketika siswa dengan kemampuan rendah dapat merespon permasalahan maka dapat membuat dirinya untuk lebih mudah memecahkan masalah dan lebih percaya diri.

\section{Keterlaksanaan Model Pembelajaran Audiotory Intellectualy Repetition (AIR).}

Hasil keterlaksanaan model pembelajaran AIR berbantuan alat peraga merupakan data yang diperoleh dari lembar pengamatan keterlaksanaan yang dilakukan oleh tiga orang pengamat yaitu satu orang guru dan dua orang mahasiswa. Pengamatan keterlaksaan ini diamati di kelas eksperimen dan dikelas kontrol dimana kelas kontrol menggunakan model pembelajaran langsung dan kelas eksperimen 
menggunakan menggunakan model pembelajaran AIR berbantuan alat peraga dengan memuat 23 kegiatan pembelajaran pada materi limas. Adapun hasil observasi keterlaksanaan model pembelajaran AIR berbantuan alat peraga, ditampilkan pada Tabel 7 sebagai berikut.

Tabel 7. Hasil Lembar Keterlaksanaan Model Pembelajaran A IR Berbantuan Alat Peraga

\begin{tabular}{lllll}
\hline $\begin{array}{l}\text { Tahapan } \\
\text { kegiatan }\end{array}$ & $\begin{array}{l}\text { Pertemuan pada } \\
\text { kelas kontrol }\end{array}$ & $\begin{array}{l}\text { Pertemuan pada } \\
\text { kelas eskperimen }\end{array}$ & $\begin{array}{l}\text { Rata- } \\
\text { rata }\end{array}$ & kriteria \\
\hline Pendahuluan & $76 \%$ & $77,1 \%$ & $76,55 \%$ & Baik \\
Inti & $65 \%$ & $75 \%$ & $70 \%$ & Baik \\
Penutup & $75 \%$ & $81,2 \%$ & $78,1 \%$ & Baik \\
\hline Rata -rata & $\mathbf{7 2 \%}$ & $\mathbf{7 7 , 7 6 \%}$ & $\mathbf{7 4 , 8 8 \%}$ & Baik \\
\hline
\end{tabular}

Pada kegiatan pendahuluan yang memuat 3 kegiatan pada pendahuluan pembelajaran yang diamati seperti guru mengucapkan salam pembuka, berdoa bersama, mengabsen siswa, apresepsi, motivasi dan tujuan pembelajaran pada pendahuluan dengan rata-rata persentasi sebasar 76,55\% dengan kriteria baik, kegiatan inti memuat tahapan pembelajaran AIR yaitu tahap a) siswa dibagi dalam beberapa kelompok, masing-masing kelompok terdiri dari 4-5 siswa, b) siswa mendengarkan dan memperhatikan penjelasan dari guru, c) setiap kelompok berdiskusi tentang materi yang mereka pelajari dan menuliskan hasil diskusi tersebut selanjutnya untuk dipersentasikan didepan kelas (audiotory), d) saat diskusi berlangsung siswa mendapatkan soal yang berkaitan dengan materi, e) masing-masing kelompok memikirkan cara menerapkan hasil diskusi serta dapat meningkatkan kemampuan untuk memecahkan masalah, f) setelah selesai diskusi, siswa mendapat pengulangan materi dengan cara mendapatkan tugas atau kuis untuk setiap individu, pada kegiatan inti dengan persentase sebesar $70 \%$ dengan kriteria baik, dan kegiatan penutup seperti menarik kesimpulan, berdoa, mengucapkan salam dengan persentase sebesar 78,1\% dengan kriteria baik.

Menurut Istarani (2014: 3) pembelajaran melalui model bertujuan untuk membantu siswa menemukan makna diri (jati diri) didalam lingkungan sosial dan memecahkan dilema dengan bantuan kelompok. Pada tahapan model pembelajaran AIR siswa mendengarkan dan memperhatikan penjelasan dari guru. Pada tahapan ini dapat menarik perhatian siswa dan siswa akan senang pada saat mengikuti proses pembelajaran. Menurut Istarani (2014: 3) fase perhatian model didalam belajar, belajar ini merupakan perhatian yang menarik yang dapat merangsang siswa untuk mempelajarinya. Dari Tabel 7 juga dapat digambarkan dalam diagram batang keterlaksanaan model pembelajaran AIR berbantuan al at peraga seperti pada Gambar 2 sebagai berikut.

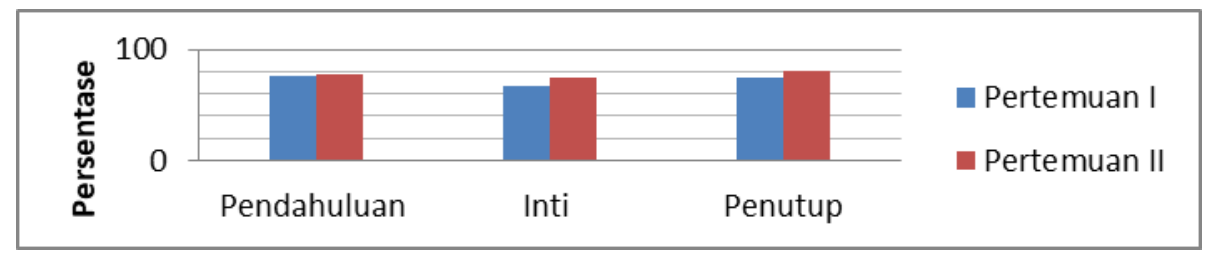

Gambar 2. Diagaram Batang Rekapitulasi Hasil Keterlaksanaan (\%)

Pada gambar diagaram di atas dapat dilihat bahwa pada pada tahap pendahuluan, inti dan penutup pada pertemuan II selalu mengalami peningkatan dari pada pertemuan I. 


\section{Journal of Educational Review and Research}

Vol. 1 No. 2, December 2018: 100 - 110

e-ISSN: 2597-9760, p-ISSN: 2597-9752

\section{Motivasi belajar Siswa}

Pada akhir proses pembelajaran dengan model AIR berbantuan alat peraga, siswa diberikan lembar angket motivasi untuk mengetahui motivsi belajar siswa selama mengikuti proses pembelajarant ersebut. Angket motivasi belajar tersebut merupakan angket tertutup dan siswa hanya memilih satu jawaban dari 5 pilihan yang diberika (sangat setuju, ragu- ragu, tidak setuju dan sangat tidak setuju) yang telah disediakan. Motivasi belajar siswa dikatakan tinggi jika motivasi belajar siswa memenuhi kriteria tinggi dan sangat tinggi.

Berdasarkan hasil perhitungan angket motivasi belajar, jumlah skor rata- rata individu sebesar 89,71 dengan rata-rata keseluruhan adalah 3,5 berada pada kriteria tinggi. Rata -rata skor keseluruhan siswa tinggi yang dilihat dari 4 indikator motivasi belajar siswa. adapun ke-4 indikator tersebut adalah a) adanya dorongan dan kebutuhan dalam belajar, b) menunjukan perhatian dan minat terhadap tugastugas yang diberikan, c) ulet menghadapi kesulitan, d) adanya hasrat dan keinginan berhasil.Hal ini menunjukan motivasi belajar siswa pada kelas eksperimen terhadap model pembelajaran AIR berbantuan alat peraga pada materi limas tergolong tinggi.

Tingginya motivasi belajar siswa pada kelas eksperimen pada penelitian ini dikarenakan pada model AIR, Siswa tidak langsung diberikan hasil akhir dari penjelasan, melainkan siswa dilatih untuk belajar menyelesaikan masalah dengan cara mereka sendiri melalui diskusi bersama teman sekelompoknya dengan bantuan guru sehingga menimbulkan keingintahuan untuk bisa menyelesaikan masalah, secara tidak langsung dapat memotivasi siswa untuk belajar. Hal ini sejalan dengan penelitian yang dilakukan Octaviani (2015: 7) menggunakan model pembelajaran AIR dapat meningkatkan motivasi belajar siswa dibandingkan model konvensional. Jadi dapat disimpulkan motivasi belajar siswa tergolong tinggi ketika diterapkan model pembelajaran AIR berbantuan alat peraga.

\section{CONCLUSION AND SUGGESTION}

Berdasarkan penelitian yang dilakukan dan pembahasan secara umum dapat disimpulkan bahwa terdapat perbedaan kemampuan pemahaman konsep matematis siswa yang mengunakan model AIR berbantuan alat peraga dengan siswa yang mengunakan pembelajaran konvensional, tingginya pengaruh model pembelajaran AIR berbantuan alat peraga terhadap kemampuan pemahaman konsep matematis siswa, keterlaksanaan model pembelajaranAIR berbantuan alat peraga tercapai dengan baik ,motivasi belajar siswa tergolong tinggi ketika diterhadapkan model pembelajaran AIR berbantuan alat peraga. Penelitian ini memiliki banyak kekurangannya, maka dari itu penulis perlu masukan dan saran dari dosen-dosen dan tim jurnal secara langsung.

\section{ACKNOWLEDGMENTS}

Penulis mengucapkan terima kasih kepada kedua orang tua saya Ayahanda Ambon dan ibunda Polina terima kasih atas kasih sayang yang telah kalian berikan atas dukungan kalian dan suport kalian sehingga jurnal ini dapat terselesaikan, dan saya mengucapkan terimaksih juga buat suami saya Deni Pranata atas dukungan suami, serta motivasinya membuat saya semakin semangat menyelesaikan jurnal ini, terimakasih banyak. Terimaksih saya ucapkan kepada seluruh dosen pendidikan Matematika STKIP Singkawang, kepada Ketua STKIP Singkawang Drs. Andi Mursidi, M.Si. kepada kedua pembimbing saya yaitu bapak Rosmaiyadi, S.Pd, M.Pd dan ibu Mariyam, S.Pd, M.Pd yang telah memberikan arahan dan bimbingan dalam penulisan artikel hasil penelitian ini. 


\section{REFERENCES}

Aris, S. (2014). Model Pembelajaran Inovatif Dalam Kurikulum 2013. Yogyakarta: Ar-Ruzz Media Ayu. (2014). Penerapan Model Pembelajaran PBI Terhadap Pemahaman Konsep Matematis Pada Materi Balok. Jurnal: Skripsi, Universitas Lampung

Depdiknas. (2007).Kurikulum 2007 Matematika Sekolah Menengah. Jakarta: Depdiknas.

Erman, Munifah. (2010). Strategi Pembelajaran Matematika Kontemporer. Bandung: JICA Universitas Pendidikan Indonesia.

Julianti, Rosmaiyadi \& Mariyam (2018). Pemahaman Konsep Matematis Siswa Dengan Strategi Pembelajaran Group To Group Exchange Berpendekatan Kontekstual. Jurnal Pendidikan Matematika Indonesia, 1(1), 1.

Klipetrik, (2001). Meningkatkan Daya Matematik Mahasiswa Calon Guru Matematika Melalui Pembelajaran Berbasis masalah. Disertasi Pascasarjana UPI Bandung

Latifha. (2013). Penggunaan Alat Peraga Meteran Untuk Meningkatkan Hasil Belajar Matematika Bagi Siswa Berkesulitan Belajar Matematika.Jurnal: Fakultas Surakarta

Lestari dan Yudanegara. (2011). Penelitian Pendidikan Matematika. Kerawang: PT Refika aditama

Rostina. (2014). Media dan Alat Peraga dalam Pembelajaran Matematika. Bandung: Cv. ALFABETA

Sari, A.N., Wahyuni, R., \& Rosmaiyadi. (2016). Penerapan Pendekatan Open-Ended untuk Meningkatkan Kemampuan Berpikir Kritis Siswa Pada Materi Aljabar Kelas VIII SMP Negeri 10 Pemangkat. Jurnal Pendidikan Matematika Indonesia, 1(1), 20-24.

Sudjana, Nana. (2010). Mengembangkan dan Membuat Alat Peraga Matematika SD, SMP dan SMA.Yogyakarta: PPPPTK Matematika.

Sulaiman. (2015). Pengaruh Penggunaan Alat Peraga Berbasis Konsep Geometri Pada Modelpembelajaran Kooperatif Tipe Think Pair Share. Jurnal : STKIP Muhamadiah Lampong

Suryani, Elsa (2016). Analisis Pemahaman Konsep Matematis Siswa Pada Materi Operasi Hitung Bilangan Bulat Kela VII Mts Ushuluddin Singkawang. Skripsi, STKIP Singkawang. Tidak dipublikasikan

Trianto. (2008). Model Pembelajaran Terpadu dalam Teori dan Praktek. Jakarta: PT. Prestasi Pustaka Wahyuni, dkk. (2013). Pengaruh Model Pembelajaran Berbasis Masalah Terhadap Pemahaman Konsep Matematis Siswa. Jurnal Pendidikan Matematika Universitas Lampung. Vol.2. No.2.

Zukardi, Supardi. (2012). Pendidikan Matematika di Indonesia. Palembang: Universitas Sriwijaya 